\title{
Factors associated with a vicious cycle involving a low nephron number, hypertension and chronic kidney disease
}

\author{
Go Kanzaki ${ }^{1}$, Nobuo Tsuboi ${ }^{1}$, Kotaro Haruhara ${ }^{1}$, Kentaro Koike ${ }^{1}$, Makoto Ogura ${ }^{1}$, Akira Shimizu ${ }^{2}$ \\ and Takashi Yokoo ${ }^{1}$
}

It has been reported that there is substantial variation in the nephron number between individuals. Previous studies using autopsy kidneys have demonstrated that a low nephron number, in relation to a low birth weight, may result in hypertension (HTN) and/or chronic kidney disease (CKD). However, recent studies have revealed that the association between a low nephron number and HTN is not a universal finding. This observation indicates that a low nephron number is unlikely to be the sole factor contributing to an elevated blood pressure. In addition to the nephron number, various genetic and congenital factors may contribute to increased susceptibility to HTN and/or CKD in a complex manner. Acquired factors, including aging, obesity and related metabolic abnormalities, and various causes of renal injury, may additionally promote further nephron loss. Such a vicious cycle may induce HTN and/or CKD via the common mechanisms of renal hemodynamic maladaptation.

Hypertension Research (2015) 38, 633-641; doi:10.1038/hr.2015.67; published online 18 June 2015

Keywords: chronic kidney disease; glomerular density; glomerular volume; nephron number

\section{INTRODUCTION}

Chronic kidney disease (CKD) is a growing health problem of epidemic proportions worldwide. Numerous randomized clinical trials and epidemiological studies have reported systemic hypertension (HTN) to be strongly associated with renal insufficiency. ${ }^{1}$ In addition, it has been established that the kidneys have an integral role in the regulation of arterial pressure. This close interaction between HTN and CKD has long been discussed in relation to the occurrence of cardiovascular disease (CVD) or end-stage renal disease. ${ }^{2}$

Since Brenner et al. ${ }^{3}$ proposed that a lower nephron number predisposes the individual to both essential HTN and chronic renal disease, the relationship between the nephron number and the adult risk of CVD and CKD has been recognized. These authors also proposed that a congenital or acquired nephron deficit may be associated with glomerular hypertrophy and intraglomerular hypertension, which may cause further nephron loss. A reduction in the nephron number results in a reduced sodium excretory capacity, enhanced susceptibility to HTN and diminished renal functional reserve, thereby limiting the extent of compensation for renal injury and progressive renal insufficiency. ${ }^{4-6}$

It has long been accepted that the human kidney contains, on average, one million nephrons. However, numerous studies conducted in the past 20 years have demonstrated that there is much greater variability in the total nephron number in normal human kidneys than previously suspected. Whereas studies agree that the average number of nephrons is approximately one million per kidney, larger studies have shown a maximal 13-fold variation in the normal human nephron number. ${ }^{6,7}$ In addition, a few recent autopsy studies have indicated that the nephron number is lower in the kidneys of patients with hypertension than in the kidneys of normotensive age-matched controls. ${ }^{8,9}$ Furthermore, the findings of a low nephron number in Australian aborigines, who exhibit an extremely high rate of renal failure, are consistent with the link between a low nephron number and CKD. ${ }^{10}$ These potential differences in the nephron number may underlie the differences in susceptibility to HTN and progression of CKD among individuals. ${ }^{11}$

In this review, we provide an update regarding findings for the nephron number and its association with HTN and/or CKD based on current knowledge and recent studies.

\section{NEPHRON NUMBER}

Estimation of the nephron number

The nephron number is estimated via the surrogate of the glomerular number (Nglom) in recent autopsy studies. A range of methods has been used to count the number of glomeruli in the kidneys over the past 100 years. To date, the gold standard method for estimating the

\footnotetext{
${ }^{1}$ Division of Nephrology and Hypertension, Department of Internal Medicine, The Jikei University School of Medicine, Tokyo, Japan and ${ }^{2}$ Department of Analytic Human Pathology, Nippon Medical School, Tokyo, Japan

Correspondence: Dr N Tsuboi, Division of Nephrology and Hypertension, Department of Internal Medicine, The Jikei University School of Medicine, 3-25-8 Nishi-Shinbashi, Minato-Ku, Tokyo, Japan.

E-mail: tsuboi-n@jikei.ac.jp

Received 9 February 2015; revised 23 March 2015; accepted 26 March 2015; published online 18 June 2015
} 
Nglom is based on the dissector principle proposed by Sterio et al. ${ }^{12}$ and the fractionator experimental design approach described by Gundersen et al. ${ }^{13}$ This method ensures that glomeruli are counted with equal probability, regardless of their size, shape or distribution within the kidney. On the basis of this background, the Nglom in human kidneys is now calculated using the unbiased fractionatorsampling/dissector-counting methodology as a surrogate marker of the nephron number. ${ }^{14,15}$

In the first of a series of autopsy studies, Nyengaard et al. ${ }^{16}$ reported an average nephron number of 617000 (331000 to 1 424000) in 37 normal Danish kidneys. In the second published study, Hoy et al. reported similar results, with a mean of 810646 (228 441 to 1825380 ) glomeruli per kidney, although with ninefold variation among 78 kidneys obtained from black and white Americans and aboriginal and white Australians. ${ }^{17}$ Despite the varying ranges of nephron numbers, other studies have shown the similar results (Table 1). Importantly, numerous subsequent studies have suggested that the nephron number is significantly linked to birth weight, race, gender, age and the mean glomerular volume. ${ }^{18}$ This suggests that the final nephron number is the result of the complex interplay between genetic and environmental factors that has through out the patient's lifetime (Table 2).

Determining factors of the nephron number

Despite the large variation in the nephron number found in these studies, one consistent observation has been noted: the human nephron number strongly and directly correlates with birth weight.
Hughson et al. ${ }^{19}$ reported that a low birth weight (LBW; defined as a birth weight under $2500 \mathrm{~g}$ ) is associated with a reduced nephron number in white and African Americans. That study calculated an increase of $\sim 260000$ glomeruli per kilogram increase in birth weight. Meanwhile, Zhang et al. ${ }^{20}$ found that the nephron number in 15 infants $<3$ months of age exhibited a range of 4.5-fold, from 246181 to 1106062 , suggesting that the range in the adult Nglom reflects not only the degree of variation in nephron loss that occurs with aging, but also the extent of variation in the nephron number at birth.

Barker et al. ${ }^{21}$ reported the concept of developmental programming of cardiovascular and renal diseases in adults as a result of intrauterine starvation leading to an abnormally LBW in infants. Subsequently, numerous animal experiments and epidemiological studies have demonstrated a similar concept, additionally focused on the association between LBW and a low nephron number. ${ }^{22,23}$ In addition, Hodgin et al. ${ }^{24}$ described the onset of secondary focal segmental glomerulosclerosis (FSGS) as being associated with proteinuria in six adults with a history of extreme prematurity, and Ikezumi et al. ${ }^{25}$ reported the number of podocytes per glomerulus in LBW-FSGS patients is lower than that seen in MCNS patients born with a normal birth weight. These findings support the hypotheses of both Barker and Brenner that LBW is associated with a reduced nephron number and therefore an increased risk of HTN/CVD and CKD in later life.

In humans, nephrogenesis begins at around the fifth week and ceases at the 36th week of gestation. ${ }^{26}$ Although nephrons continue to mature and the kidney increases in size during childhood, the nephron number does not increase. Therefore, it has been assumed that the

Table 1 Nephron number in humans

\begin{tabular}{|c|c|c|c|c|c|c|}
\hline Population & $\mathrm{N}$ & Age (years) & Nglom & Fold & Range & Reference \\
\hline Danish & 37 & 58 & 617000 & 4.3 & $331000-1424000$ & 16 \\
\hline \multicolumn{7}{|l|}{ Germany } \\
\hline HTN (+) & 10 & 45.5 & 702379 & 3.7 & 531 140-1 959914 & 8 \\
\hline \multirow[t]{4}{*}{ HTN (-) } & 10 & 46.5 & 1429200 & & & \\
\hline & 25 & $42.4 \pm 13.0$ & $861205 \pm 327454$ & & & 17 \\
\hline & 37 & $29.2 \pm 14.2$ & $959306 \pm 328602$ & & & 19 \\
\hline & 39 & $41.6 \pm 13.8$ & 904412 & 5.1 & $395054-2026541$ & 52 \\
\hline \multicolumn{7}{|l|}{ African Americans } \\
\hline HTN (+) & 59 & 46 & $885279 \pm 333619$ & 1.8 & $682664-1198257$ & 38 \\
\hline $\operatorname{HTN}(-)$ & 48 & 34 & $951807 \pm 268798$ & & & \\
\hline HTN (+) & 86 & 46 & $953558 \pm 350054^{a}$ & 12.8 & $210332-2702079$ & 9 \\
\hline \multirow[t]{4}{*}{$\operatorname{HTN}(-)$} & 61 & 35 & $1021582 \pm 326581^{a}$ & & & \\
\hline & 17 & $47.9 \pm 18.4$ & $858721 \pm 325579^{b}$ & & & 17 \\
\hline & 15 & $42.5 \pm 15.6$ & $861205 \pm 327454^{c}$ & & & 17 \\
\hline & 19 & $28.7 \pm 17.7$ & $869959 \pm 286006$ & & & 19 \\
\hline \multicolumn{7}{|l|}{ White } \\
\hline HTN (+) & 32 & 49 & $841069 \pm 291903$ & 1.8 & $651793-1146986$ & 38 \\
\hline HTN (-) & 55 & 41 & $901011 \pm 298334$ & & & \\
\hline HTN (+) & 44 & 49 & $946339 \pm 348970^{a}$ & 12.8 & $210332-2702079$ & 9 \\
\hline HTN (-) & 79 & 42 & $1019957 \pm 319696^{a}$ & & & \\
\hline \multirow[t]{2}{*}{ Aboriginal } & 10 & $42.0 \pm 13.9$ & $782671 \pm 248070$ & & & 17 \\
\hline & 17 & $38.5 \pm 12.4$ & 683174 & 3.1 & $364262-1129233$ & 10 \\
\hline \multirow[t]{2}{*}{ Senegalese Africans } & 28 & $34.9 \pm 19.7$ & $925485 \pm 225427$ & 2.6 & $536171-1394010$ & 102 \\
\hline & 39 & $42.3 \pm 14.9$ & 937967 & 3.3 & $536171-1764421$ & 52 \\
\hline
\end{tabular}

Abbreviations: HTN, hypertension; Nglom, glomerular number.

amale.

${ }^{\mathrm{b}}$ Australian white.

American white. 
Table 2 Congenital and acquired factors associated with the nephron number

\begin{tabular}{ll}
\hline & Details \\
\hline $\begin{array}{l}\text { Congenital factors } \\
\text { Genes } \\
\text { Birth weight }\end{array}$ & PAX2, RET \\
Gender & Low birth weight \\
Race & Female \\
Maternal nutrition & Aborigine \\
& Low protein, vitamin A deficiency, hyperglycemia \\
Acquired factors & \\
Postnatal nutrition & \\
Medicine & Low calorie/protein \\
Age & ACE inhibitor, steroid \\
Kidney disease & Older \\
Nephrectomy & Nephropathy, diabetes, cystic disease \\
Obesity/pregnancy & Trauma, tumor \\
\hline
\end{tabular}

Abbreviation: ACE, angiotensin-converting enzyme.

nephron number is strongly influenced by the fetal environment. Many animal models have demonstrated an association between a low nephron number and gestational exposure to stimuli of a maternal origin, such as a low-protein diet, ${ }^{27}$ dexamethasone, ${ }^{28}$ vitamin A deficiency, ${ }^{29}$ excessive alcohol consumption, ${ }^{30}$ a high vitamin $\mathrm{D}$ level, ${ }^{31}$ anemia $^{32}$ and hyperglycemia. ${ }^{33}$ Moreover, Painter et al. ${ }^{34}$ reported that Dutch individuals exposed to famine in gestation had higher rates of microalbuminuria as adults than those who had not been exposed to famine in utero. This effect was not mediated by a reduced maternal weight or small size of the infant at birth. The authors implied that gestational undernutrition results in a reduced nephron number at birth and a consequent increased risk of microalbuminuria. ${ }^{34}$ These results suggest that environmental factors, such as the maternal nutritional status and health environment, may affect the determination of the individual nephron number.

Birth weight alone may not be a universal surrogate marker of the nephron number. Other programmed factors associated with the nephron number include race, gender and various genes. As shown in Table 1, the kidneys of Australian aborigines contain significantly fewer nephrons than that observed in other populations. Of note, this population is well known for an extremely high incidence of CKD. ${ }^{35,36}$ Meanwhile, there are no differences in the nephron number between white and African Americans. ${ }^{37,38}$ A female gender has been shown to be associated with $\sim 12-17 \%$ fewer nephrons than that noted in males. ${ }^{39}$ This finding is consistent with the fact that females tend to have a lower birth weight than males in the general population. Furthermore, Murphy et al $^{40}$ reported that the placental level of 11beta-hydroxysteroid dehydrogenase type 2 is higher in mothers carrying female fetuses. This means that male fetuses may be exposed to higher levels of glucocorticoids than female fetuses.

The process of nephrogenesis is regulated by numerous genes and signaling cascades. Polymorphisms in some of these genes have been investigated in relation to the nephron number in humans. Recently, more than 25 genes in rodents have been shown to result in renal hypoplasia and a low nephron number. ${ }^{41}$ These phenotypes involve alterations in the nephron endowment and present as apparent renal malformations, agenesis and/or hypodysplasia. For example, the PAX2AAA haplotype causes a $10 \%$ reduction in the kidney volume. ${ }^{42}$ Similarly, RET1476A, a polymorphic variant, is associated with an almost $10 \%$ reduction in the kidney volume, ${ }^{20}$ and mutations in several other genes also result in a reduced nephron number. ${ }^{43}$ For example, the glial cell line-derived neurotrophic factor gene (GDNF) allele results in a reduced nephron endowment in the adult kidney, presumably as the result of reduced branching morphogenesis of the ureteric bud. ${ }^{44}$ However, a study analyzing polymorphisms in the GDNF genes did not find an association with renal hypoplasia. ${ }^{45}$

\section{Causes of reductions in the nephron number}

Conversely, in several previous studies, a low nephron number has been reported in the absence of LBW, and not all LBW individuals display a reduced nephron number. ${ }^{46}$ In addition, the variability in the nephron number (Nglom) in the adult kidneys is due to variations not only in nephrogenesis during gestation, but also in the rate of nephron loss during childhood and/or adult life. After birth and throughout adulthood, only loss of the nephron mass occurs. Therefore, the rate of reduction in the nephron number is expected to vary among individuals depending on these factors, including absolute nephron reduction factors (aging, kidney disease and nephrectomy) and factors associated with a relative increase in body mass (catch-up growth, obesity and pregnancy). These factors may additionally increase the single-nephron glomerular filtration rate as a compensatory phenomenon involving exhaustion of the reserved filtration capacity. It has been postulated that glomerular hyperfiltration may be associated with the occurrence of glomerulosclerosis by raising the glomerular wall tension and by also stretching and damaging the glomerular epithelial cells. ${ }^{47}$ However, a recent study has shown the development of glomerular hyperfiltration following donor nephrectomy to not be associated with the development of glomerular hypertension or an impairment of the kidney function. ${ }^{48}$ Therefore, glomerular hyperfiltration followed by compensatory mechanisms is not considered to be the main risk factor for further nephron loss, but it is likely to increase the risk that a reduction in the nephron number may occur.

Aging is likely the most important factor influencing the nephron number in normal adults. Older individuals have fewer nephrons due to age-related obsolescence. Several studies have also shown that the nephron number progressively decreases due to glomerulosclerosis as a result of intrarenal atherosclerosis and renal ischemia. ${ }^{49,50}$ In one study, when four racial groups were analyzed together, the nephron number was found to be inversely correlated with age. ${ }^{51}$ The same study demonstrated a decrease in the nephron number of 4179 per year associated with normal aging. In addition, McNamara et al. ${ }^{52}$ reported an inverse association between the nephron number and age as well as age-associated increases in arteriosclerosis, cortical fibrosis and glomerulosclerosis. These findings indicate that the reduced number of glomeruli observed with increasing age is due to glomerular loss secondary to glomerulosclerosis caused by arteriolosclerosis.

For this reason, a congenitally reduced number of nephrons may increase susceptibility to renal injury later in life. In addition, acquired factors may act as a secondary insult to the kidney and thus further perpetuate disease progression.

\section{Imaging analyses of the nephron number}

Current techniques for counting the nephron number are applicable only in autopsy studies. Non-invasive methods for obtaining direct measurements of the nephron number in vivo have not yet been established and must be developed to monitor the nephron number in patients at risk of HTN/CVD and/or CKD.

Recent studies have attempted to estimate the nephron number using non-invasive analyses of the fine structure of the kidneys using magnetic resonance imaging (MRI). ${ }^{53,54}$ This method is based on the observation that labeling glomeruli with cationic ferritin (CF) in vivo 
allows for the whole-kidney detection of each labeled glomerulus. Although the total MRI-based count is lower than the stereological count, the error is within $10 \%$. Beeman et al. ${ }^{55}$ measured the glomerular number and volume in intact human kidneys using this approach. They further demonstrated MRI-detectable changes in the glomerular and vascular morphology in the setting of renal vascular disease and hypertension. These MRI techniques thus have the potential to enable direct measurements of the actual nephron number in living subjects.

Renal pathological changes associated with a low nephron number Glomerular size. Although the nephron number does not increase after birth, the kidney matches its filtration capacity to the body's demands by increasing the size of nephrons via hypertrophy. Most studies of human Nglom have reported a strong inverse correlation between the Nglom and the mean glomerular volume (Vglom). In an autopsy series, the Vglom showed a 6.7-fold range, exhibiting a close relationship with BMI, Nglom, birth weight and hypertension. ${ }^{56}$ Consistently, glomerulomegaly is frequently found in renal biopsies of Australian aborigines with a reduced nephron endowment, whose rates of LBW and renal disease are high. ${ }^{57}$ These findings suggest that larger glomeruli may be a sign of compensatory hyperfiltration and hypertrophy in subjects with a fewer number of nephrons. Compensatory hypertrophied glomeruli may be more susceptible to hyperfiltration and glomerulosclerosis. Such hemodynamic changes associated with enlarged glomeruli have been also described in other disorders, such as obesity-related glomerulopathy, diabetes mellitus, polycystic kidney disease and secondary FSGS. ${ }^{47}$ In addition, Hughson et al. ${ }^{58}$ have shown that, in the setting of mild-to-moderate nephrosclerosis, glomerular hypertrophy is identified as an integral feature of hypertensive nephropathy and appears to precede rather than compensate for glomerulosclerosis. The glomerular size may therefore be an additional risk factor predisposing the patient to HTN and CKD.

Glomerulosclerosis. An inverse correlation between the total nephron number and glomerulosclerosis is observed in adult autopsy studies. ${ }^{57}$ Glomerulosclerosis also directly correlates with the mean arterial pressure. In renal pathology, the two patterns of glomerulosclerosis may occur in relation to aging and HTN. One pattern involves the onset of glomerulosclerosis that is proceeded by a sequence of ischemic changes. As the glomerular tuft contracts, fibrous connective tissue fills Bowman's space with acellular fibrous tissue. The other pattern of glomerulosclerosis is referred to as glomerular solidification, which consists of an increase in the mesangial matrix, subsequently resulting in either segmental or global solidification of the glomerular tuft. $^{59}$ On the basis of these findings, a low nephron number, as a result of glomerular hyperfiltration damage, may lead to arteriolosclerosis in the preglomerular arteries as well as glomerulosclerosis due to ischemia and solidification.

Glomerular density. The significance of the nephron number is now well appreciated. Recently, the concept of the glomerular density

Table 3 Reports on the glomerular density in subjects with a normal renal function

\begin{tabular}{|c|c|c|c|c|c|c|c|}
\hline Race & Objects & $\mathrm{N}$ & Age & $G D$ & Methods & Findings & Reference \\
\hline \multicolumn{8}{|c|}{ Autopsy Studies } \\
\hline Slovenian & $\begin{array}{l}\text { Accident } \\
\text { deaths }\end{array}$ & 20 & 21.5 years & $2.9 \mathrm{~mm}^{-2}$ & $\begin{array}{l}\text { The number of all glomeruli } \\
\text { within the cortical area }\end{array}$ & $\begin{array}{l}\text { A significant correlation } \\
\text { between GD and birth } \\
\text { weights }\end{array}$ & 61 \\
\hline \multirow[t]{2}{*}{ Cuban } & LBW & 18 & $37.0 \pm 1.05$ weeks & $92.9 \pm 4.85$ & $\begin{array}{l}\text { The number of glomeruli per } \\
0.6 \mathrm{~mm}^{2} \text { of renal cortex }\end{array}$ & $\begin{array}{l}\text { A strong correlations } \\
\text { between glomerular number } \\
\text { (direct) and size (inverse) } \\
\text { with LBW }\end{array}$ & 62 \\
\hline & NBW & 17 & $38.9 \pm 1.29$ weeks & $105.8 \pm 3.91$ & & & \\
\hline Japanese & $\begin{array}{l}\text { Disease } \\
\text { deaths }\end{array}$ & 89 & $63 \pm 14$ years & $2.6 \pm 0.6 \mathrm{~mm}^{-2}$ & $\begin{array}{l}\text { The number of non- } \\
\text { scleroticglomeruli per } 4-8 \\
\text { fields ( } 6 \mathrm{~mm}^{2} \text { /each) ran- } \\
\text { domly selected in the renal } \\
\text { cortical area }\end{array}$ & $\begin{array}{l}\text { GD showed maximal 3.5- } \\
\text { fold variations between } \\
\text { individuals and was inver- } \\
\text { sely correlated with the } \\
\text { mean GV }\end{array}$ & 70 \\
\hline \multicolumn{8}{|l|}{ Biopsy Studies } \\
\hline US citizens & $\begin{array}{l}\text { Adult living } \\
\text { kidney } \\
\text { donors }\end{array}$ & 1046 & $43 \pm 12$ & $2.3 \pm 0.8 \mathrm{~mm}^{-2}$ & $\begin{array}{l}\text { The length and width of the } \\
\text { biopsy section measured by } \\
\text { a ruler. }\end{array}$ & $\begin{array}{l}\text { Decreased GD was asso- } \\
\text { ciated with kidney function } \\
\text { and metabolic risk factors }\end{array}$ & 64 \\
\hline \multirow[t]{4}{*}{ Japanese } & IgAN & 98 & $34 \pm 13$ & $3.5 \pm 1.5 \mathrm{~mm}^{-2}$ & $\begin{array}{l}\text { The total renal cortical area } \\
\text { of the biopsy section mea- } \\
\text { sured using a computed } \\
\text { imaging analyzer }\end{array}$ & $\begin{array}{l}\text { GD exhibited significant } \\
\text { variation in patients with } \\
\text { various primary glomerular } \\
\text { disease and was a plausible } \\
\text { independent predictor of } \\
\text { disease progression }\end{array}$ & $\begin{array}{l}65 \\
66\end{array}$ \\
\hline & MN & 65 & $56 \pm 14$ & $3.4 \pm 1.1 \mathrm{~mm}^{-2}$ & & & 67 \\
\hline & MCNS & 50 & $39 \pm 18$ & $3.6 \pm 1.1 \mathrm{~mm}^{-2}$ & & & 68 \\
\hline & ORG & 20 & $40 \pm 12$ & $1.7 \pm 0.6 \mathrm{~mm}^{-2}$ & & & 107 \\
\hline
\end{tabular}

Abbreviations: GD, glomerular density, IgAN, IgA nephropathy; LBW, low birth weight; MCD, minimal change disease; MN, membranous nephropathy; NBW, normal birth weight; ORG, obesityrelated glomerulopathy. 
(GD; glomerular number per renal cortical area) was introduced, indicating the histological significance of the nephron number ${ }^{60}$ (Table 3).

A previous report showed that the GD is correlated with birth weight, a known factor related to the total nephron number. ${ }^{61}$ Interestingly, Manalich et al. ${ }^{62}$ reported that the kidneys of low birth weight neonates contain fewer glomeruli per unit area of cortex than those of neonates with a normal birth weight. In addition, Rothermund et al. ${ }^{63}$ measured the GD as a surrogate for the nephron number in Munich-Wistar-Frömter (MWF) rats, a well-established model of a genetic reduction in the glomerular number of the order of $50 \%$ compared with control rats. At 12 weeks of age, the glomerular density was $12.1 \pm 3.1$ number $/ \mathrm{mm}^{3}$ vs. $7.3 \pm 1.6$ number $/ \mathrm{mm}^{3}$ in the Wistar and MWF strains, respectively. ${ }^{63}$ Furthermore, Rule et al. ${ }^{64}$ indicated that the GD is associated with the kidney function and other metabolic characteristics, such as body mass index, hypertension and/or high-density lipoprotein cholesterol, based on the findings of renal biopsy samples in healthy adult kidney donors. ${ }^{64} \mathrm{We}$ also previously demonstrated that the individual value of the GD in renal tissue specimens obtained via percutaneous needle biopsy shows an approximately sevenfold variation in cases of IgA nephropathy (IgAN) ${ }^{65,66}$ a fourfold variation in cases of membranous nephropathy (MN) ${ }^{67}$ and a fourfold variation in cases of minimal change disease $(\mathrm{MCD}),{ }^{68}$ even in patients with a preserved renal function. In addition, a low GD on biopsy specimens is associated with a poor long-term renal prognosis and/or blunted response to corticosteroid therapy in these patients. ${ }^{66-68}$ Similarly, our study using biopsy samples in patients with hypertensive nephrosclerosis suggested that the GD may reflect the severity of proteinuria in this population. ${ }^{69}$ Subsequently, our recent study using autopsy kidneys obtained from 89 individuals without apparent renal disease, which enabled the evaluation of a much larger number of glomeruli than that permitted using biopsy specimens, showed a maximal 3.5-fold variation in the GD. ${ }^{70}$ In addition, we previously reported the GD is inversely correlated with the mean glomerular volume (GV) (Figure 1), consistent with our previous findings obtained with biopsy specimens.

These findings led us to hypothesize that the GD, at least in part, reflects the personal nephron number of each individual. This hypothesis should be confirmed in further studies.

\section{NEPHRON NUMBER AND HYPERTENSION}

Blood pressure and the nephron number

HTN has been reported to be related not only to renal dysfunction (injury or ischemic), but also to many disorders of the vascular, cardiac and central nervous systems. However, the mechanisms involved in the development and maintenance of HTN have not yet been completely elucidated.

A low nephron endowment has long been identified as a risk factor for the development of HTN in animal experiments and human autopsy studies. ${ }^{71}$ In addition, experimental studies have shown the linkage of oligonephronia (a low nephron number) and HTN, to cause an alteration in the tubular sodium transporters expression, vascular function, neuroendocrine adaptation and sympathetic regulation. ${ }^{72}$ Although these results indicate that a low nephron endowment is associated with elevation of arterial blood pressure, recent studies have shown that this association is not a universal finding. Our findings therefore suggest that additional factors that lead to the occurrence of a low nephron number cause structural or functional changes in the kidneys that eventually lead to HTN. Further studies are required to unravel the mechanistic links between blood pressure and the nephron number.

\section{Animal experiments}

Some animal experiments, using rat fetuses exposed to maternal protein restriction, have suggested a strong link between the nephron number at birth and the postnatal blood pressure. ${ }^{73,74}$ For example, Schreuder et al. ${ }^{75}$ reported that rats born after spontaneous IUGR have a low nephron endowment and become hypertensive. In addition, spontaneous hypertensive rat strains have fewer glomeruli than normotensive rats, ${ }^{76}$ and Ots et al. ${ }^{77}$ showed that a reduced renal mass is the major factor involved in the development and maintenance of arterial hypertension and glomerular injury in 5/6 nephrectomized rats and that these changes can be reversed by supplementing the renal mass. These results provide strong support for the notion that the renal mass is a significant, independent determinant of arterial pressure. Cullen-McEwen et al. ${ }^{78}$ reported an elevated arterial pressure and glomerular hypertrophy in aged GDNF heterozygous mice. Moreover, Walker et al. ${ }^{79}$ showed that an augmented nephron endowment in transforming growth factor- $\beta 2$ heterozygous (Tgfb2 $(+/-))$ mice protects against the hypertensive effects of a chronic high-salt diet. This finding is consistent with the hypothesis that the

b
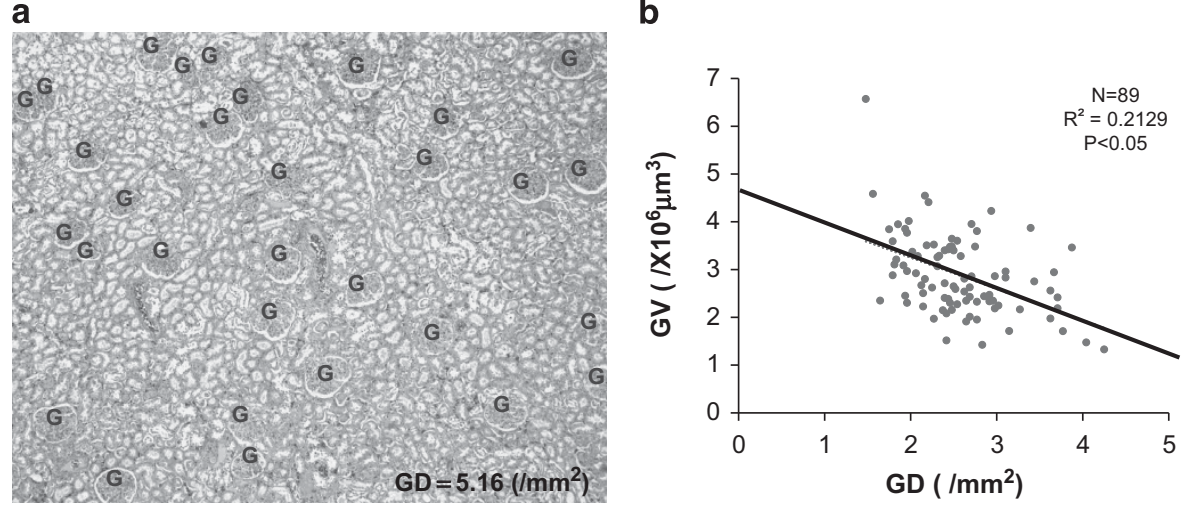

Figure $1 \mathrm{GD}$ in an autopsy study. (a) Representative renal histological findings in an autopsy case. Autopsy kidney specimens obtained from a 67-year-old female with an estimated glomerular filtration rate (eGFR) of $89 \mathrm{ml} \mathrm{min}{ }^{-1}$ per $1.73 \mathrm{~m}^{2}$ are shown (original magnification $\times 100$; Masson's trichrome stain). In this case, the GD was estimated to be $5.16 \mathrm{~mm}^{2}{ }^{2}$. G, glomerulus. (b) Relationship between the GD and GV in the autopsy kidneys. The GD showed a close inverse correlation with the GV. A full color version of this figure is available at Hypertension Research online. 
nephron endowment modulates the risk of developing cardiovascular and/or renal diseases.

Meanwhile, several animal studies have suggested that even marked nephron deficiency and hyperfiltration do not always lead to HTN or renal dysfunction. Notably, Ruta et al. ${ }^{80}$ found that neither moderate $(25 \%)$ nor severe $(65 \%)$ reductions in the nephron endowment impact blood pressure (BP) in GDNF heterozygous mice at 1 year of age. Recent studies have also indicated that a low nephron number increases the risk of hypertension in animals exposed to secondary adverse stimuli, such as a high-salt diet. These findings, obtained utilizing a genetic model of a reduced nephron endowment, suggest that deficits in the nephron number alone do not always directly translate to hypertension or renal disease. ${ }^{81}$

\section{Human studies}

Keller et al. ${ }^{8}$ analyzed a consecutive series of subjects who died in accidents and described that the number of glomeruli was lower in the kidneys of the patients with hypertension than in the kidneys of the matched normotensive controls. In particular, the number of glomeruli was diminished by $\sim 46 \%$ in the hypertensive individuals, and the mean glomerular volume was markedly increased by $\sim 50 \%$. This study strongly supports the presence of an association between a low nephron number and HTN in humans. Samuel et al. ${ }^{82}$ also showed that the glomerular number is significantly reduced in subjects with hypertension, in association with a significant increase in the mean glomerular volume, independent of the body surface area. However, the precise mechanisms involved in the increases in blood pressure in individuals with a low nephron endowment have not yet been fully elucidated. One possible effect of a low nephron endowment is a reduction in the number of sodium transporters as well as alterations in renal sodium handling, which may influence blood pressure control.

Similarly, the association between the nephron number and blood pressure has been investigated in several populations, including Germans, aboriginal Australians, white and African Americans and Senegalese Africans. In these studies, however, a low nephron number was not always found to be associated with HTN. ${ }^{83}$ In particular, no association between the nephron number and BP has been found in either white Americans, African Americans or Senegalese Africans. ${ }^{9}$ This observation indicates that a low nephron number is unlikely to be the sole factor contributing to elevated BP. In addition to the nephron number, other programmed factors associated with an increased risk of hypertension may include salt sensitivity, an altered expression of renal sodium transporters, altered vascular reactivity, modulation of the activity of the RAS, sympathetic nervous system overactivity and dysfunction of the cardiovascular system. ${ }^{84}$

\section{Renal renin-angiotensin system and the nephron number}

Nephrogenesis. The renal renin-angiotensin system (RAS) has been identified to have a role in regulating the renal function and arterial pressure in adults as well as promoting the structural and functional development of the fetal kidney. ${ }^{85}$ Woods et al. ${ }^{86}$ showed that perinatal blockade of angiotensin II (AII) angiotensin type1 (AT1) receptors results in fewer, albeit enlarged glomeruli, a reduced renal function and an increased arterial pressure in newborn SpragueDawley rats. In addition, AII binding to the AT1 receptor has been shown in culture systems to mediate the process of branching morphogenesis. ${ }^{87}$ Therefore, a decreased expression of the AT1 receptor may result in less branching of the ureteric bud and thus a reduction in the nephron number. Similarly, the gestational use of ACE-I may be associated with a high degree of fetal and newborn renal failure or prolonged HTN in humans ${ }^{88}$ Following the completion of nephrogenesis, AT1 receptors appear to be upregulated in the kidneys of offspring. Moreover, Salazar et al. ${ }^{89}$ showed that AII modulation modifies the renal function and induces the development of AII-dependent hypertension that becomes sodium-sensitive with aging. This finding may provide a mechanistic link with activation of the renal RAS, which may cause sodium retention and elevated blood pressure..$^{90}$ On the basis of these findings, a lower expression of RAS components during the active period of nephrogenesis is associated with a lower nephron number and HTN in later life. It has also been shown that AII stimulates the expression of $\mathrm{Pax}-2$ via angiotensin II type 2 receptors and thus affects the onset of nephrogenesis and kidney development. ${ }^{91}$

Treatment of glomerular hyperfiltration caused by a low nephron number. Glomerular hyperfiltration associated with a low nephron number may activate the RAS, which results in maladaptive renal and systemic hemodynamic responses, increased arterial stiffness and endothelial dysfunction. Previous animal studies have also shown that experimental reductions in the nephron number are closely associated with glomerular enlargement, together with increased activation of the intrarenal RAS. ${ }^{92}$ The most effective intervention for a low nephron number, therefore, may be to target glomerular hypertension and the RAS.

Of note, it has been demonstrated that a transient decrease in GFR following treatment with an angiotensin receptor blocker (losartan) in patients with diabetic nephropathy is associated with a subsequent reduction in the slope of the renal function..$^{93}$ This amelioration of glomerular hypertension in patients with a transient decrease in GFR may indicate dependence pathophysiologically on the RAS. Therefore, a transient decrease in GFR following the administration of RAS inhibitors may be a candidate surrogate marker of a relative reduction in the nephron number.

\section{NEPHRON NUMBER AND CKD}

\section{Proteinuria and the nephron number}

Numerous studies have reported an increased prevalence of microalbuminuria and proteinuria among adults born with LBW. ${ }^{94}$ In a study of Australian aborigines, an odds ratio of 2.8 for albuminuria was found in those with a history of LBW vs. NBW. ${ }^{95}$ Similarly, among Pima Indians with type 2 diabetes, a U-shaped association has been demonstrated between birth weight and albumin excretion in both LBW and high-birth weight (HBW; defined as a birth weight over 4500 g) adults. ${ }^{96}$ Meanwhile, Jones et al. ${ }^{97}$ described morphological abnormalities in glomerular podocytes in LBW diabetic animals, which may have a role in the development of proteinuria. ${ }^{97}$ These findings likely indicate that intrauterine programming of nephron development may be associated with a decreased nephron number and increased risk of albuminuria.

\section{Renal insufficiency and the nephron number}

A recent meta-analysis found a 70\% increase (odds ratio 1.73) in the relative risk of CKD associated with LBW. ${ }^{98}$ In some animal models, congenital nephron deficiency, both genetic and experimental, is associated with renal disease and renal failure in postnatal life. LBW animals with a reduced nephron number have also shown to exhibit abnormal glomerular adaptation and greater renal injury. ${ }^{99}$ In contrast, Li et al. ${ }^{100}$ reported a U-shaped association between birth weight and CKD prevalence among males, but not females, in a screened volunteer population in the National Kidney Foundation's Kidney Early Evaluation. Although it is certainly recognized that the rate of 


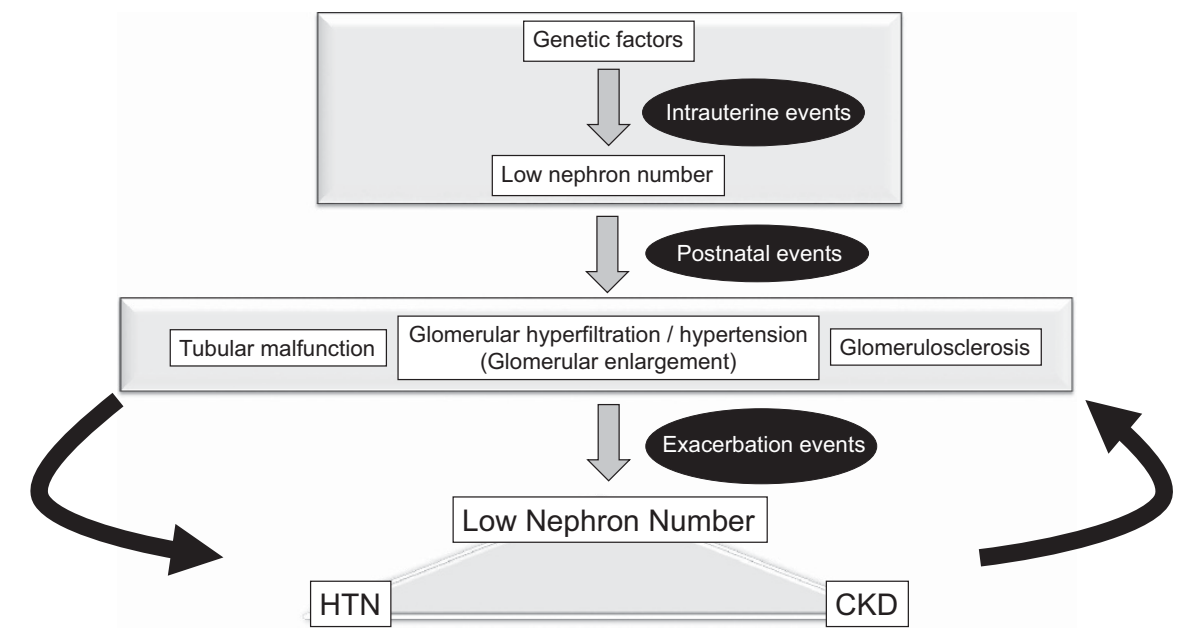

Figure 2 Hypothetical mechanism of nephron number reduction. Three events, intrauterine, postnatal or exacerbation, affect the reduction in the human nephron number. Beginning at the top and moving to the bottom, multiple factors induce further nephron loss, which leads to a vicious cycle among a low nephron number, HTN and CKD via renal hemodynamic maladaptation.

CKD in patients who have undergone partial nephrectomy for renal cell carcinoma is higher than that observed in the general population, ${ }^{101}$ few studies have analyzed the direct relationships between the human nephron number and prevalence of CKD. ${ }^{102}$

Researchers have recently suggested that kidneys with a congenitally reduced nephron number, displaying less functional reserve, may also be anticipated to be more susceptible to subsequent renal injury and functional decline. ${ }^{103,104}$ In fact, in a model of LBW with the subsequent induction of diabetes, Jones et al. ${ }^{105}$ demonstrated that LBW animals have a reduced nephron number and that LBW diabetic rats exhibit a greater proportional increase in renal size and glomerular hypertrophy compared with normal birth weight controls after one week of diabetes. That study demonstrated that the renal response to injury in the setting of a reduced nephron number may result in accelerated loss of the renal function. Consistent with this possibility, an LBW status has been shown to be associated with poorer outcomes in patients with chronic glomerulonephritis or diabetic nephropathy. ${ }^{23}$ These results suggest that LBW is associated with both the initiation and progression of $\mathrm{CKD}$.

\section{CONCLUSIONS}

As previously reviewed, ${ }^{106}$ various genetic, congenital and acquired factors have been reported to be associated with a vicious cycle involving a low nephron number, hypertension and chronic kidney disease (Figure 2). Although the association between these three characteristics is not present in all studies, the nephron number is undoubtedly a strong determinant of blood pressure and the risk of renal disease in later life. Therefore, evaluating the nephron number in each patient is currently one of the most important issues in this field. However, counting the nephron number is labor-intensive and expensive and not utilized at most laboratories. Therefore, the development of new methods to non-invasively estimate the individual nephron number would be very useful for evaluating the future CVD/ HTN risk and progression of renal disease.

\section{CONFLICT OF INTEREST}

The authors declare no conflict of interest.

\section{ACKNOWLEDGEMENTS}

Part of this study was supported by the Japan Kidney Foundation Research Fund and a Grant-in-Aid for Scientific Research (C) (N.T.).

1 Coresh J, Wei GL, McQuillan G, Brancati FL, Levey AS, Jones C, Klag MJ. Prevalence of high blood pressure and elevated serum creatinine level in the United States: findings from the third National Health and Nutrition Examination Survey (1988-1994). Arch Intern Med 2001; 161: 1207-1216.

2 Chronic Kidney Disease Prognosis Consortium, Matsushita K, van der Velde M, Astor BC, Woodward M, Levey AS, de Jong PE, Coresh J, Gansevoort RT. Association of estimated glomerular filtration rate and albuminuria with all-cause and cardiovascular mortality in general population cohorts: a collaborative meta-analysis. Lancet 2010; 375: 2073-2081.

3 Brenner BM, Garcia DL, Anderson S. Glomeruli and blood pressure. Less of one, more the other? Am J Hypertens 1988; 1: 335-347.

4 Luyckx VA, Brenner BM. The clinical importance of nephron mass. J Am Soc Nephrol 2010; 21: 898-910.

5 Wakasugi M, Kazama JJ, Yamamoto S, Kawamura K, Narita I. A combination of healthy lifestyle factors is associated with a decreased incidence of chronic kidney disease: a population-based cohort study. Hypertens Res 2013; 36: 328-333.

6 Ohta Y, Tsuchihashi T, Kiyohara K, Oniki H. High salt intake promotes a decline in renal function in hypertensive patients: a 10-year observational study. Hypertens Res 2013; 36: 172-176.

7 Hoy WE, Ingelfinger JR, Hallan S, Hughson MD, Mott SA, Bertram JF. The early development of the kidney and implications for future health. J Dev Orig Health Dis 2010; 1: 216-233.

8 Keller G, Zimmer G, Mall G, Ritz E, Amann K. Nephron number in patients with primary hypertension. N Engl J Med 2003; 348: 101-108.

9 Hughson MD, Douglas-Denton R, Bertram JF, Hoy WE. Hypertension, glomerular number, and birth weight in African Americans and white subjects in the southeastern United States. Kidney Int 2006; 69: 671-678.

10 Hoy WE, Hughson MD, Singh GR, Douglas-Denton R, Bertram JF. Reduced nephron number and glomerulomegaly in Australian Aborigines: a group at high risk for renal disease and hypertension. Kidney Int 2006; 70: 104-110.

11 Abitbol CL, Ingelfinger JR. Nephron mass and cardiovascular and renal disease risks. Semin Nephrol 2009; 29: 445-454.

12 Sterio DC. The unbiased estimation of number and sizes of arbitrary particles using the disector. J Microsc 1984; 134: 127-136.

13 Gundersen HJ, Bendtsen TF, Korbo L, Marcussen N, Møller A, Nielsen K, Nyengaard JR, Pakkenberg B, Sørensen FB, Vesterby A. Some new, simple and efficient stereological methods and their use in pathological research and diagnosis. APMIS 1988; 96: 379-394.

14 Bertram JF. Counting in the kidney. Kidney Int 2001; 59: 792-796.

15 Cullen-McEwen LA, Douglas-Denton RN, Bertram JF. Estimating total nephron number in the adult kidney using the physical disector/fractionator combination. Methods Mol Biol 2012; 886: 333-350.

16 Nyengaard JR, Bendtsen TF. Glomerular number and size in relation to age, kidney weight, and body surface in normal man. Anat Rec 1992; 232: 194-201. 
17 Hoy WE, Douglas-Denton RN, Hughson MD, Cass A, Johnson K, Bertram JF. A stereological study of glomerular number and volume: preliminary findings in a multiracial study of kidneys at autopsy. Kidney Int Supp/ 2003; 83: S31-S37.

18 Puelles VG, Hoy WE, Hughson MD, Diouf B, Douglas-Denton RN, Bertram JF. Glomerular number and size variability and risk for kidney disease. Curr Opin Nephrol Hypertens 2011; 20: 7-15.

19 Hughson M, Farris AB 3rd, Douglas-Denton R, Hoy WE, Bertram JF. Glomerular number and size in autopsy kidneys: the relationship to birth weight. Kidney Int 2003; 63: 2113-2122.

20 Zhang Z, Quinlan J, Hoy W, Hughson MD, Lemire M, Hudson T, Hueber PA, Benjamin A, Roy A, Pascuet E, Goodyer M, Raju C, Houghton F, Bertram J, Goodyer P. A common RET variant is associated with reduced newborn kidney size and function. $J$ Am Soc Nephrol 2008; 19: 2027-2034.

21 Barker DJ, Bagby SP. Developmental antecedents of cardiovascular disease: a historical perspective. J Am Soc Nephrol 2005; 16: 2537-2544.

22 Moritz KM, Dodic M, Wintour EM. Kidney development and the fetal programming of adult disease. Bioessays 2003; 25: 212-220.

23 Luyckx VA, Brenner BM. Low birth weight, nephron number, and kidney disease. Kidney Int Supp/ 2005; 97: S68-S77.

24 Hodgin JB, Rasoulpour M, Markowitz GS, D'Agati VD. Very low birth weight is a risk factor for secondary focal segmental glomerulosclerosis. Clin J Am Soc Nephrol 2009; 4: 71-76.

25 Ikezumi Y, Suzuki T, Karasawa T, Yamada T, Hasegawa H, Nishimura H, Uchiyama M. Low birthweight and premature birth are risk factors for podocytopenia and focal segmental glomerulosclerosis. Am J Nephrol 2013; 38: 149-157.

26 Kett MM, Denton KM. Renal programming: cause for concern? Am J Physiol Regul Integr Comp Physiol 2011; 300: R791-R803.

27 Almeida JR, Mandarim-de-Lacerda CA. Maternal gestational protein-calorie restriction decreases the number of glomeruli and causes glomerular hypertrophy in adult hypertensive rats. Am J Obstet Gynecol 2005; 192: 945-951.

28 Ortiz LA, Quan A, Weinberg A, Baum M. Effect of prenatal dexamethasone on rat renal development. Kidney Int 2001; 59: 1663-1669.

29 Xu Q, Lucio-Cazana J, Kitamura M, Ruan X, Fine LG, Norman JT. Retinoids in nephrology: promises and pitfalls. Kidney Int 2004; 66: 2119-2131.

30 Gray SP, Cullen-McEwen LA, Bertram JF, Moritz KM. Mechanism of alcohol-induced impairment in renal development: Could it be reduced by retinoic acid? Clin Exp Pharmacol Physiol 2012; 39: 807-813.

31 Maka N, Makrakis J, Parkington HC, Tare M, Morley R, Black MJ. Vitamin D deficiency during pregnancy and lactation stimulates nephrogenesis in rat offspring. Pediat Nephrol 2008; 23: 55-61.

32 Crowe C, Dandekar P, Fox M, Dhingra K, Bennet L, Hanson MA. The effects of anaemia on heart, placenta and body weight, and blood pressure in fetal and neonatal rats. J Physiol 1995; 488: 515-519.

33 Hokke SN, Armitage JA, Puelles VG, Short KM, Jones L, Smyth IM, Bertram JF, Cullen-McEwen LA. Altered ureteric branching morphogenesis and nephron endowment in offspring of diabetic and insulin-treated pregnancy. PLOS ONE 2013; 8: e58243.

34 Painter RC, Roseboom TJ, van Montfrans GA, Bossuyt PM, Krediet RT, Osmond C, Barker DJ, Bleker OP. Microalbuminuria in adults after prenatal exposure to the Dutch famine. J Am Soc Nephrol 2005; 16: 189-194.

35 Hoy WE, Wang Z, VanBuynder P, Baker PR, Mathews JD. The natural history of rena disease in Australian Aborigines. Part 1. Changes in albuminuria and glomerular filtration rate over time. Kidney Int 2001; 60: 243-248.

36 Hoy WE, Wang Z, VanBuynder P, Baker PR, McDonald SM, Mathews JD. The natural history of renal disease in Australian Aborigines. Part 2. Albuminuria predicts natural death and renal failure. Kidney Int 2001; 60: 249-256.

37 Hoy WE, Hughson MD, Bertram JF, Douglas-Denton R, Amann K. Nephron number, hypertension, renal disease, and renal failure. J Am Soc Nephrol 2005; 16 2557-2564.

38 Hughson MD, Gobe GC, Hoy WE, Manning RD Jr, Douglas-Denton R, Bertram JF. Associations of glomerular number and birth weight with clinicopathological features of African Americans and whites. Am J Kidney Dis 2008; 52: 18-28.

39 Luyckx VA, Shukha K, Brenner BM. Low nephron number and its clinical consequences. Rambam Maimonides Med J 2011; 2: e0061.

40 Murphy VE, Fittock RJ, Zarzycki PK, Delahunty MM, Smith R, Clifton VL. Metabolism of synthetic steroids by the human placenta. Placenta 2007; 28: 39-46.

41 Luyckx VA, Bertram JF, Brenner BM, Fall C, Hoy WE, Ozanne SE, Vikse BE. Effect of fetal and child health on kidney development and long-term risk of hypertension and kidney disease. Lancet 2013; 382: 273-283.

42 Quinlan J, Lemire M, Hudson T, Qu H, Benjamin A, Roy A, Pascuet E, Goodyer M, Raju C, Zhang Z, Houghton F, Goodyer P. A common variant of the PAX2 gene is associated with reduced newborn kidney size. J Am Soc Nephrol 2007; 18: 1915-1921.

43 Kemper MJ, Müller-Wiefel DE. Renal function in congenital anomalies of the kidney and urinary tract. Curr Opin Urol 2001; 11: 571-575.

44 Cullen-McEwen LA, Drago J, Bertram JF. Nephron endowment in glial cell line-derived neurotrophic factor (GDNF) heterozygous mice. Kidney Int 2001; 60: 31-36.

45 Zhang Z, Quinlan J, Grote D, Lemire M, Hudson T, Benjamin A, Roy A, Pascuet E, Goodyer M, Raju C, Houghton F, Bouchard M, Goodyer P. Common variants of the glial cell-derived neurotrophic factor gene do not influence kidney size of the healthy newborn. Pediatr Nephrol 2009; 24: 1151-1157.
46 Moritz KM, Singh RR, Probyn ME, Denton KM. Developmental programming of a reduced nephron endowment: more than just a baby's birth weight. Am J Physiol Renal Physiol 2009; 296: F1-F9.

47 Helal I, Fick-Brosnahan GM, Reed-Gitomer B, Schrier RW. Glomerular hyperfiltration: definitions, mechanisms and clinical implications. Nat Rev Nephrol 2012; 8 293-300.

48 Lenihan CR, Busque S, Derby G, Blouch K, Myers BD, Tan JC. Longitudinal study of living kidney donor glomerular dynamics after nephrectomy. J Clin Invest 2015; 125 1311-1318.

49 Glassock RJ, Rule AD. The implications of anatomical and functional changes of the aging kidney: with an emphasis on the glomeruli. Kidney Int 2012; 82: 270-277.

50 Rule AD, Amer H, Cornell LD, Taler SJ, Cosio FG, Kremers WK, Textor SC, Stegall MD. The association between age and nephrosclerosis on renal biopsy among healthy adults. Ann Intern Med 2010; 152: 561-567.

51 Douglas-Denton RN, McNamara BJ, Hoy WE, Hughson MD, Bertram JF. Does nephron number matter in the development of kidney disease? Ethn Dis 2006; 16 (2Suppl 2): S2-40-5.

52 McNamara BJ, Diouf B, Douglas-Denton RN, Hughson MD, Hoy WE, Bertram JF. A comparison of nephron number, glomerular volume and kidney weight in Senegalese Africans and African Americans. Nephrol Dial Transplant 2010; 25: 1514-1520.

53 Beeman SC, Zhang M, Gubhaju L, Wu T, Bertram JF, Frakes DH, Cherry BR Bennett KM. Measuring glomerular number and size in perfused kidneys using MRI Am J Physiol Renal Physiol 2011; 300: F1454-F1457.

54 Heilmann M, Neudecker S, Wolf I, Gubhaju L, Sticht C, Schock-Kusch D, Kriz W, Bertram JF, Schad LR, Gretz N. Quantification of glomerular number and size distribution in normal rat kidneys using magnetic resonance imaging. Nephrol Dial Transplant 2012; 27: 100-107.

55 Beeman SC, Cullen-McEwen LA, Puelles VG, Zhang M, Wu T, Baldelomar EJ, Dowling J, Charlton JR, Forbes MS, Ng A, Wu QZ, Armitage JA, Egan GF, Bertram JF, Bennett KM. MRI-based glomerular morphology and pathology in whole human kidneys. Am J Physiol Renal Physiol 2014; 306: F1381-F1390.

56 Bertram JF, Douglas-Denton RN, Diouf B, Hughson MD, Hoy WE. Human nephron number: implications for health and disease. Pediatr Nephrol 2011; 26 $1529-1533$

57 Young RJ, Hoy WE, Kincaid-Smith P, Seymour AE, Bertram JF. Glomerular size and glomerulosclerosis in Australian aborigines. Am J Kidney Dis 2000; 36: 481-489.

58 Hughson MD, Puelles VG, Hoy WE, Douglas-Denton RN, Mott SA, Bertram JF. Hypertension, glomerular hypertrophy and nephrosclerosis: the effect of race. Nephrol Dial Transplant 2014; 29: 1399-1409.

59 Hughson MD, Johnson K, Young RJ, Hoy WE, Bertram JF. Glomerular size and glomerulosclerosis: relationships to disease categories, glomerular solidification, and ischemic obsolescence. Am J Kidney Dis 2002; 39: 679-688.

60 Tsuboi N, Kanzaki G, Koike K, Kawamura T, Ogura M, Yokoo T. Clinicopathological assessment of the nephron number. Clin Kidney J 2014; 7: 107-114.

61 Zidar N, Cör A, Premru Srsen T, Stajer D. Is there an association between glomerular density and birth weight in healthy humans. Nephron 1998; 80: 97-98.

62 Mañalich R, Reyes L, Herrera M, Melendi C, Fundora I. Relationship between weight at birth and the number and size of renal glomeruli in humans: a histomorphometric study. Kidney Int 2000; 58: 770-773.

63 Rothermund L, Nierhaus M, Fialkowski O, Freese F, Ibscher R, Mieschel S, Kossmeh P, Grimm D, Wehland M, Kreutz R. Genetic low nephron number hypertension is associated with dysregulation of the hepatic and renal insulin-like growth factor system during nephrogenesis. J Hypertens 2006; 24: 1857-1864.

64 Rule AD, Semret MH, Amer H, Cornell LD, Taler SJ, Lieske JC, Melton LI 3rd, Stegall MD, Textor SC, Kremers WK, Lerman LO. Association of kidney function and metabolic risk factors with density of glomeruli on renal biopsy samples from living donors. Mayo Clin Proc 2011; 86: 282-290.

65 Tsuboi N, Kawamura T, Ishii T, Utsunomiya Y, Hosoya T. Changes in the glomerular density and size in serial renal biopsies during the progression of IgA nephropathy. Nephrol Dial Transplant 2009; 24: 892-899.

66 Tsuboi N, Kawamura T, Koike K, Okonogi H, Hirano K, Hamaguchi A, Miyazaki Y, Ogura M, Joh K, Utsunomiya Y, Hosoya T. Glomerular density in renal biopsy specimens predicts the long-term prognosis of IgA nephropathy. Clin J Am Soc Nephrol 2010; 5: 39-44.

67 Tsuboi N, Kawamura T, Miyazaki Y, Utsunomiya Y, Hosoya T. Low glomerular density is a risk factor for progression in idiopathic membranous nephropathy. Nephrol Dial Transplant 2011; 26: 3555-3560.

68 Koike K, Tsuboi N, Utsunomiya Y, Kawamura T, Hosoya T. Glomerular densityassociated changes in clinicopathological features of minimal change nephrotic syndrome in adults. Am J Nephrol 2011; 34: 542-548.

69 Haruhara K, Tsuboi N, Kanzaki G, Koike K, Suyama M, Shimizu A, Miyazaki Y, Kawamura T, Ogura M, Yokoo T. Glomerular density in biopsy-proven hypertensive nephrosclerosis. Am J Hypertens (e-pub ahead of print 27 January 2015).

70 Kanzaki G, Tsuboi N, Utsunomiya Y, Ikegami M, Shimizu A, Hosoya T. Distribution of glomerular density in different cortical zones of the human kidney. Pathol Int 2013, 63: 169-175.

71 Zandi-Nejad K, Luyckx VA, Brenner BM. Adult hypertension and kidney disease: the role of fetal programming. Hypertension 2006; 47: 502-508.

72 Nuyt AM, Alexander BT. Developmental programming and hypertension. Curr Opin Nephrol Hypertens 2009; 18 (2): 144-152.

73 Langley-Evans SC, Welham SJ, Jackson AA. Fetal exposure to a maternal low protein diet impairs nephrogenesis and promotes hypertension in the rat. Life Sci 1999; 64: 965-974. 
74 Woods LL, Weeks DA, Rasch R. Programming of adult blood pressure by maternal protein restriction: role of nephrogenesis. Kidney Int 2004; 65: 1339-1348.

75 Schreuder MF, van Wijk JA, Delemarre-van de Waal HA. Intrauterine growth restriction increases blood pressure and central pulse pressure measured with telemetry in aging rats. J Hypertens 2006; 24: 1337-1343.

76 Skov K, Nyengaard JR, Korsgaard N, Mulvany MJ. Number and size of renal glomeruli in spontaneously hypertensive rats. J Hypertens 1994; 12: 1373-1376.

77 Ots M, Troy JL, Rennke HG, Mackenzie HS, Brenner BM. Impact of the supplementation of kidney mass on blood pressure and progression of kidney disease. Nephrol Dial Transplant 2004; 19: 337-341.

78 Cullen-McEwen LA, Kett MM, Dowling J, Anderson WP, Bertram JF. Nephron number, renal function, and arterial pressure in aged GDNF heterozygous mice. Hypertension 2003; 41: 335-340.

79 Walker KA, Cai X, Caruana G, Thomas MC, Bertram JF, Kett MM. High nephron endowment protects against salt-induced hypertension. Am J Physiol Renal Physiol 2012; 303: F253-F258.

80 Ruta LA, Dickinson H, Thomas MC, Denton KM, Anderson WP, Kett MM. High-salt diet reveals the hypertensive and renal effects of reduced nephron endowment. Am J Physiol Renal Physiol 2010; 298: F1384-F1392.

81 Zimanyi MA, Bertram JF, Black MJ. Does a nephron deficit in rats predispose to saltsensitive hypertension? Kidney Blood Press Res 2004; 27: 239-247.

82 Samuel T, Hoy WE, Douglas-Denton R, Hughson MD, Bertram JF. Determinants of glomerular volume in different cortical zones of the human kidney. J Am Soc Nephrol 2005; 16: 3102-3109.

83 Hoy WE, Bertram JF, Denton RD, Zimanyi M, Samuel T, Hughson MD. Nephron number, glomerular volume, renal disease and hypertension. Curr Opin Nephrol Hypertens 2008; 17: 258-265.

84 Abitbol CL, Rodriguez MM. The long-term renal and cardiovascular consequences of prematurity. Nat Rev Nephrol 2012; 8: 265-274.

85 Guron G, Friberg P. An intact renin-angiotensin system is a prerequisite for normal renal development. J Hypertens 2000; 18: 123-137.

86 Woods LL, Rasch R. Perinatal ANG II programs adult blood pressure, glomerular number, and renal function in rats. Am J Physiol 1998; 275: R1593-R1599.

87 Yosypiv IV, El-Dahr SS. Role of the renin-angiotensin system in the development of the ureteric bud and renal collecting system. Pediatr Nephrol 2005; 20: 1219-1229.

88 Shotan A, Widerhorn J, Hurst A, Elkayam U. Risks of angiotensin-converting enzyme inhibition during pregnancy: experimental and clinical evidence, potential mechanisms, and recommendations for use. Am J Med 1994; 96: 451-456.

89 Salazar F, Reverte V, Saez F, Loria A, Llinas MT, Salazar FJ. Age- and sodium-sensitive hypertension and sex-dependent renal changes in rats with a reduced nephron number. Hypertension 2008; 51: 1184-1189.

90 Ichihara A, Kobori H, Nishiyama A, Navar LG. Renal renin-angiotensin system. Contrib Nephrol 2004; 143: 117-130.

91 Zhang SL, Moini B, Ingelfinger JR. Angiotensin II increases Pax-2 expression in fetal kidney cells via the AT2 receptor. J Am Soc Nephrol 2004; 15: 1452-1465.

92 Anderson S, Rennke HG, Brenner BM. Therapeutic advantage of converting enzyme inhibitors in arresting progressive renal disease associated with systemic hypertension in the rat. J Clin Invest 1986; 77: 1993-2000.
93 Holtkamp FA, de Zeeuw D, Thomas MC, Cooper ME, de Graeff PA, Hillege HJ, Parving $\mathrm{HH}$, Brenner BM, Shahinfar S, Lambers Heerspink HJ. An acute fall in estimated glomerular filtration rate during treatment with losartan predicts a slower decrease in long-term renal function. Kidney Int 2011; 80: 282-287.

94 Hoy WE, Rees M, Kile E, Mathews JD, McCredie DA, Pugsley DJ, Wang Z. Low birthweight and renal disease in Australian aborigines. Lancet 1998; 352: 1826-1827.

95 Hoy WE, Rees M, Kile E, Mathews JD, Wang Z. A new dimension to the Barker hypothesis: low birthweight and susceptibility to renal disease. Kidney Int 1999; 56: 1072-1077.

96 Nelson RG, Morgenstern H, Bennett PH. Birth weight and renal disease in Pima Indians with type 2 diabetes mellitus. Am J Epidemiol 1998; 148: 650-656.

97 Jones SE, White KE, Flyvbjerg A, Marshall SM. The effect of intrauterine environment and low glomerular number on the histological changes in diabetic glomerulosclerosis. Diabetologia 2006; 49: 191-199.

98 White SL, Perkovic V, Cass A, Chang CL, Poulter NR, Spector T, Haysom L, Craig JC, Salmi IA, Chadban SJ, Huxley RR. Is low birth weight an antecedent of CKD in later life? A systematic review of observational studies. Am J Kidney Dis 2009; 54: 248-261.

99 Nwagwu MO, Cook A, Langley-Evans SC. Evidence of progressive deterioration of renal function in rats exposed to a maternal low-protein diet in utero. Br J Nutr 2000; 83: 79-85.

100 Li S, Chen SC, Shlipak M, Bakris G, McCullough PA, Sowers J, Stevens L, Jurkovitz C, McFarlane S, Norris K, Vassalotti J, Klag MJ, Brown WW, Narva A, Calhoun D, Johnson B, Obialo C, Whaley-Connell A, Becker B, Collins AJ. Kidney Early Evaluation Program Investigators. Low birth weight is associated with chronic kidney disease only in men. Kidney Int 2008; 73: 637-642.

$101 \mathrm{Li}$ L, Lau WL, Rhee CM, Harley K, Kovesdy CP, Sim JJ, Jacobsen S, Chang A, Landman J, Kalantar-Zadeh K. Risk of chronic kidney disease after cancer nephrectomy. Nat Rev Nephrol 2014; 10: 135-145.

102 McNamara BJ, Diouf B, Hughson MD, Douglas-Denton RN, Hoy WE, Bertram JF. Renal pathology, glomerular number and volume in a West African urban community. Nephrol Dial Transplant 2008; 23: 2576-2585.

103 Schreuder MF, Nauta J. Prenatal programming of nephron number and blood pressure. Kidney Int 2007; 72: 265-268.

104 Ritz E, Amann K, Koleganova N, Benz K. Prenatal programming-effects on blood pressure and renal function. Nat Rev Nephrol 2011; 7: 137-144.

105 Jones SE, Bilous RW, Flyvbjerg A, Marshall SM. Intra-uterine environment influences glomerular number and the acute renal adaptation to experimental diabetes. Diabetologia 2001; 44: 721-728.

106 Nenov VD, Taal MW, Sakharova OV, Brenner BM. Multi-hit nature of chronic renal disease. Curr Opin Nephrol Hypertens 2000; 9: 85-97.

107 Tsuboi N, Utsunomiya Y, Kanzaki G, Koike K, Ikegami M, Kawamura T, Hosoya T. Low glomerular density with glomerulomegaly in obesity-related glomerulopathy. Clin J Am Soc Nephrol 2012: 7: 735-741. 